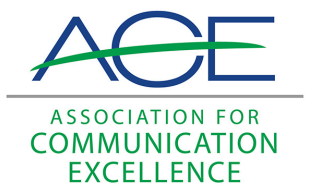

Journal of Applied Communications

\title{
Table of contents, editorial board, and other front matter for vol. 79, no. 1 (1995) of Journal of Applied Communications
}

Larry Tennyson

South Dakota State University

Follow this and additional works at: https://newprairiepress.org/jac cc) (ㅇ)

This work is licensed under a Creative Commons Attribution-Noncommercial-Share Alike 4.0 License.

\section{Recommended Citation}

Tennyson, Larry (1995) "Table of contents, editorial board, and other front matter for vol. 79, no. 1 (1995) of Journal of Applied Communications," Journal of Applied Communications: Vol. 79: Iss. 1. https://doi.org/10.4148/1051-0834.1362

This Introduction is brought to you for free and open access by New Prairie Press. It has been accepted for inclusion in Journal of Applied Communications by an authorized administrator of New Prairie Press. For more information, please contact cads@k-state.edu. 
Table of contents, editorial board, and other front matter for vol. 79, no. 1 (1995) of Journal of Applied Communications

\section{Abstract}

Editorial front matter and table of contents for vol. 79, no. 1 (1995) of Journal of Applied Communications 
Volume 79

No. 1. 1995

Department Head Perceptions of the Need for Distance Education in the Agricultural Sciences

Diffusion of Agricultural Health and Safety Information: A Study of Farmers/Extension Agricultural Engineers

The Effectiveness of Delivering Leader Training Lessons Via Satellite

Evaluation of a County Extension Office's Use of Mass Media: A User Perspective

Reviews
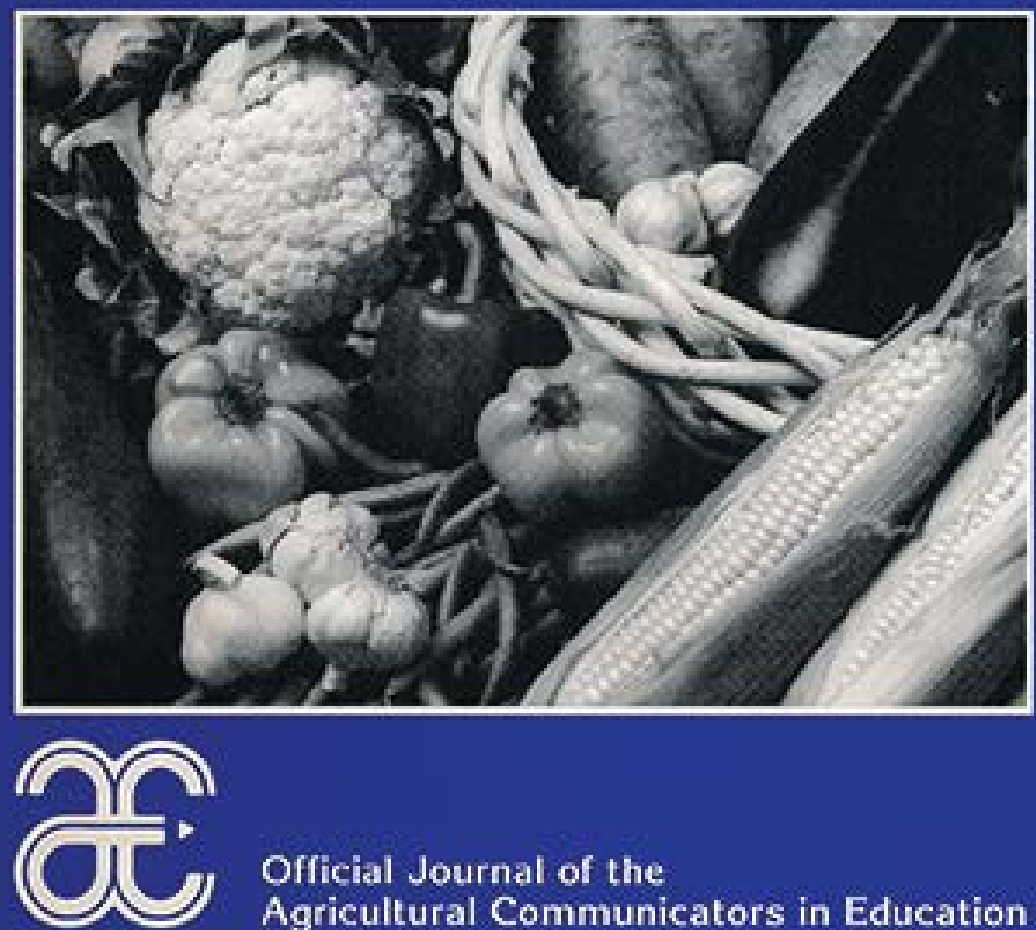

Official Journal of the

Agricultural Communicators in Education 
Journal of Applied Communications, Vol. 79, Iss. 1 [1995], Art. 1

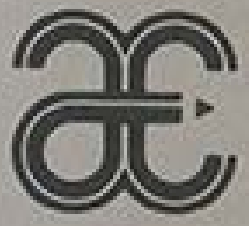

Editorial Board

Melva Berkland,

lowa State University, 1993.96.

John Brien.

Macquarie University,

New South Wales. Australia. 1994.97.

John Brooks.

Lovisiana State University. 1991.95 .

Jeanne Gleason,

New Mexico State University. 1993.96 .

Jan Scholl.

Pennsylvania State University. $1994 \cdot 97$.

Larry Tennyson, Chair. South Dakota University, 1991.95 .

Subscription rates Members of ACE receive the Journal of Applied Communica. Uions as part of regular membership services. The rate for nonmem. bers, libraries, and others is $\$ 75$ a year. Single copies of back issues may be obtained for \$15 each, when available.

\section{Editors}

Joyce Dolbler

JJDEGNVIFAS.UFL.EDU

Julie Graddy

JCGEGNV.IFAS.UFL.EDU

Kathryn Schreyer

KASCHEGNV.IFAS.UFL.EDU

Ron Thomas

RKTEGNV.IFAS,UFL.EDU

University of Florida

PO Box 110810

Gainesville, FL 32611.0810

\section{Managing Editor}

Ashley M. Wood

ACE Coordinator

AMWEGNVIFAS.UFL.EDU

Change of address notices and subscription requests should be sent to the following address:

ACE Coordinator University of Florida PO Box 110810

Gainesville, FL 32611-0810.

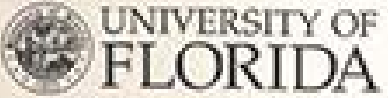

The Journat of Ayplied Cormmenications is pablished by the Agricultural Communicators in Education at the Instituse of Food and Agricultural Sciences. University of HoridaGainesville, Florids, USA. 
Tennyson: Table of contents, editorial board, and other front matter for vo

\section{Manuscript Reviewers}

Robert Agunga

Ohio Sante Universily

Blarnilo E. Bowen

Ponn State Ciniversity

Joks Brien

Mocquarle Univerilty

New South Wales, Nustrolia

Joha Breoks

Loulblana Scate Univerilty

Sam Brengerdt

Universiny of Minnewota

Mary L Cliky.

University of Florido

Karen Cronla

Vinginla Tech University

Terence L Day

Woshlington State Urfiversity

LaRae M. Doneellan

University of ldaho

Cheryl Frenk

Univerality of bilinols

Robert Kays

Universiny of 1 llinois

Denals Hinkamp

dtoh Stote Universlity

Lyn Jarvis

Iniversiby of Vermont

J. Robert Kern

Communicason for

Agrikulture Worldwide

Davld A. Klog

Purdoe University

Ken Kingaley

Qregon Stote University

J. Steven Lay

University of Alaika

Evelyn Uss

Oregon Staco Unversiay

Joe Marks

Unlversity of Mssouri

Haven Miger

University of Kertucky

Anita Povich

University of atinols

Boonle Plochert

University of Tennessee

Janet Redekohi

Univeralty of Oesorgio

Ricky Telg

Texs ASM Univorsity

Mark Tucker

Univetsity of Missout

\section{Cover photo}

This issue's cover photo became the Silver Award winner in the Photography.

Color Transparency category of the 1994 Critique $\&$ Awards Contest. The photo. shot in $35 \mathrm{~mm}$ color and BEW, was initially used in color in the Spring 1993 issue of Loulstana Agricul. ture magazine to illustrate an article entitled, "Con. sumer Percelved Health Risks with Food." The photo Illustration was directed by Betsy Meely and John Worniak; the photographer was John Woznlak. The vegetables were selected after a two-and-one-half hour search of local formers markets and supermarket produce counters. The vegetables were washed, prepped, arranged, and spritzed with water. The studio shot was accomplished with a Speedoton Brownline 800 ws power pack with 2 flash heads, 1 reflector, and a $40^{\circ} \times 40^{\circ}$ soft box as the main light source.

For more information about ACE, the Journal of Applied Communications, or Manuscript Submission Guidelines, see the last four pages of this issue. 
Journal of Applied Communications, Vol. 79, Iss. 1 [1995], Art. 1 
Journal of

\section{Applied Communications}

Volume 79

No. 1. 1995

1 Department Head Perceptions of the Need for Distance Education in the Agricultural Sciences

Blannie E. Bowen

Joan $\mathrm{S}$. Thomson

Pennsylvania State University

13 Diffusion of Agricultural Health and Safety Information: A Study of Farmers and Extension Agricultural Engineers

Judy B. Oskam

Texas Tech University

26 The Effectiveness of Delivering Leader

Training Lessons Via Satellite

Carl Mesecher

University of Nebraska-Lincoln

34 Evaluation of a County Extension Office's Use of Mass Media: A User Perspective John Fett

Theresa Shinners-Gray

Kathleen Duffy

Cara Doyle

University of Wisconsin-Madison

45 Reviews

Harlan Lynn - University of Missouri

Kathryn Schreyer - University of Florida 


\section{Illustrations}

Each issue of the Journal of Applied Communications features graphic- and photo-image winners in the Agricultural Communicators in Education Critique and Awards Program, an annual competition designed to promote member abilities and evaluate projects while offering feedback.

This issue of the Journal features the work of Melanie Eirich, University of Nebraska, 1994 Silver Award Winner in the Critique and Awards Program, Class 30b-Illustrations: Series. See pages 12,25 , and 33 for further information. 